Chapter 15

\title{
Hepatocellular Carcinoma, Steroid Hormones and Metalloproteases
}

\author{
Noemí Eiró, Belen Fernandez-Garcia, Antonio Altadill, Luis O. González and \\ Francisco J. Vizoso
}

Additional information is available at the end of the chapter

http://dx.doi.org/10.5772/56877

\section{Introduction}

Liver cancer is the fifth and seventh most frequently diagnosed cancer worldwide in men and women, respectively, but the second most frequent cause of cancer death in men [1]. In addition, hepatocellular carcinoma (HCC) represents the major histological subtype of primary liver cancers, accounting up to $90 \%$ of the total liver cancer burden worldwide [2]. The incidence of HCC has increased significantly over the past 10 years and is expected to increase because of the actual high prevalence of viral hepatitis $\mathrm{C}$-seropositive individuals and also because of the known long latency period to HCC development from the initial hepatitis $\mathrm{C}$ virus (HCV) infection, which may take 2-3 decades [3]. Despite of the varied treatment options, the prognosis of HCC remains poor. Thus, estimated 5-year survival rates are in the range of $26 \%$ to $50 \%$, and disease-free survival is $13 \%$ to $29 \%$ [4]. At present, systemic chemotherapy is quite ineffective in HCC treatment, and is also known to express the multidrugresistance gene MDR-1 [5]. Therefore, is necessary to identify and characterize molecular abnormalities of clinical significance in HCC. Besides the heterogeneity of different HCC subtypes, these tumors may use different cellular pathways and oncogenic mechanisms at different development stages, and this is of essential importance to develop biologically-based clinical trials.

\section{Steroid hormone receptors and hepatocellular carcinoma}

Although sex differences in liver cancer may be attributed to differences in lifestyle [6-8], there are several epidemiological and experimental studies suggesting that HCC might be, in part, hormone-related. Liver cancer is predominantly a male disease, with approximately three 
times higher incidence and mortality among men than women [9]. This male predominance is further supported by the fact that chronic liver disease progresses more rapidly to cirrhosis in males than in females, and therefore cirrhosis-derived HCC is largely seen in men and postmenopausal women disease [10].

The role of estrogens in modulating morphological and physiological features of liver became evident in early 1970s when a possible correlation between occurrence of hepatic neoplasms and use of oral contraceptives was suggested [11-12]. On the basis of these data, several in vitro and in vivo studies have explored the importance of sex hormones in HCC. Animal modelbased studies indicate that sex hormones play a key role in tumor progression, showing that ovarian estrogens protect against tumor progression, whereas androgens promote tumorigenesis [13-15]. It has been reported that the protective effect of estrogens against chemically induced liver tumors is mediated by prolactin (PRL) through liver prolactin receptors (PRLR) [16-18]. Nevertheless, the precise role of male and female sex hormones and their receptors in HCC remains still poorly understood. There is not enough information regarding the mechanism of estrogen and androgen in HCC.

Estrogen and androgen mediate their biological functions through binding to their specific receptors, the estrogen receptor (ER) and the androgen receptor (AR). Both ER and AR belong to the nuclear receptors family that, as transcription factors, regulate the expression level of several genes such as those involved in triggering immune responses, cell proliferation and apoptosis [19-21]. Therefore, sex hormones play a key role in normal physiology of organs other than these of the reproductive system.

Variable expressions of ER and AR has been found in normal liver and HCC using different methods, such as immunohistochemistry, enzyme-immuno assays, or determining mRNA levels (Table 1 and Table 2 give the details of these studies for ER and AR, respectively), which indicate a relationship between sex hormones and pathogenesis of HCC. The percentage of positivity for these receptors varied between the different studies [22]. These differences may be due to several methodological aspects, such as differences in the origin of the studied patients populations, sample types or technologies determining the receptor expression. In a recent study, we determined the expression of sex hormones receptors in 31 HCC patients by immunohistochemistry using tissue micro-arrays technology [23]. Our results demonstrate a wide variability in the immunohistochemical values for steroid receptors among HCCs: $67.7 \%$ of tumors stained positively for AR, 51.6\% for ER and 83.8\% for progesterone receptor (PgR), but, among the positive cases, immunostaining score values for each protein were largely variable.

\begin{tabular}{lcccccccc}
\hline Reference Protein /mRNA & $\begin{array}{c}\text { Type of liver } \\
\text { tissue }\end{array}$ & Method & Localization & $\mathbf{n}$ & $\begin{array}{c}\% \\
\text { positive } \\
\text { cases }\end{array}$ & Country & Year \\
\hline$[122]$ & ER protein & Normal & BA & cytosolic & 4 & 100 & United Kingdom & 1978 \\
\hline$[123]$ & ER protein & Normal & BA & - & 3 & 100 & Germany & 1978 \\
\hline$[124]$ & ER protein & Normal & BA & - & 2 & 100 & United States & 1982 \\
\hline
\end{tabular}




\begin{tabular}{|c|c|c|c|c|c|c|c|c|}
\hline Reference & Protein /mRNA & $\begin{array}{c}\text { Type of liver } \\
\text { tissue }\end{array}$ & Method & Localization & $\mathbf{n}$ & $\begin{array}{c}\% \\
\text { positive } \\
\text { cases }\end{array}$ & Country & Year \\
\hline [125] & ER protein & Normal & BA & - & 6 & 100 & Germany & 1982 \\
\hline$[126]$ & ER protein & Normal & BA & - & 6 & 100 & United States & 1983 \\
\hline [127] & ER protein & Normal & BA & $\begin{array}{c}\text { cytosolic and } \\
\text { nuclear }\end{array}$ & 4 & 100 & United Kingdom & 1983 \\
\hline$[128]$ & ER protein & Surrounding & BA & cytosolic & 30 & 43 & Japan & 1986 \\
\hline [129] & ER protein & Non-cancerous & BA & $\begin{array}{c}\text { cytosolic and } \\
\text { nuclear }\end{array}$ & 7 & 43 & Japan & 1986 \\
\hline [130] & ER protein & Non-cirrhotic & EIA & cytosolic & 12 & 12 & Japan & 1987 \\
\hline [131] & ER protein & Normal & & - & 2 & 2 & Japan & 1988 \\
\hline$[132]$ & ER protein & Surrounding & BA & cytosolic & 17 & 65 & Japan & 1989 \\
\hline [133] & ER protein & Surrounding & & & 22 & 64 & Japan & 1989 \\
\hline [134] & ER protein & Surrounding & BA & cytosolic & 5 & 100 & Japan & 1990 \\
\hline [135] & ER protein & Normal & BA & & 9 & 9 & $\begin{array}{c}\text { United States, } \\
\text { Italy }\end{array}$ & 1991 \\
\hline$[52]$ & ER protein & Non-cancerous & BA & cytosolic & 26 & 42 & Spain & 1993 \\
\hline$[136]$ & ER mRNA & Non-cancerous & ISH & & 13 & 54 & Italy & 1993 \\
\hline [137] & ER mRNA & Peritumoral & RT-PCR & - & 32 & 88 & Korea & 2006 \\
\hline$[124]$ & ER protein & $\mathrm{HCC}$ & BA & cytosolic & 5 & 100 & United States & 1982 \\
\hline [127] & ER protein & $\mathrm{HCC}$ & BA & $\begin{array}{c}\text { cytosolic and } \\
\text { nuclear }\end{array}$ & 5 & 100 & United Kingdom & 1983 \\
\hline [138] & ER protein & $\mathrm{HCC}$ & $\mathrm{IHC}$ & cytosolic & 10 & 10 & Singapore & 1984 \\
\hline [128] & ER protein & $\mathrm{HCC}$ & BA & cytosolic & 30 & 40 & Japan & 1986 \\
\hline [139] & ER protein & $\mathrm{HCC}$ & BA & $\begin{array}{c}\text { cytosolic and } \\
\text { nuclear }\end{array}$ & 8 & 13 & Japan & 1986 \\
\hline$[130]$ & ER protein & $\mathrm{HCC}$ & EIA & cytosolic & 13 & 38 & Japan & 1987 \\
\hline$[132]$ & ER protein & $\mathrm{HCC}$ & BA & cytosolic & 19 & 37 & Japan & 1989 \\
\hline$[24]$ & ER protein & $\mathrm{HCC}$ & BA & cytosolic & 66 & 39 & Japan & 1990 \\
\hline [134] & ER protein & $\mathrm{HCC}$ & BA & cytosolic & 6 & 17 & Japan & 1990 \\
\hline [140] & ER protein & $\mathrm{HCC}$ & BA & cytosolic & 21 & 48 & Japan & 1991 \\
\hline [141] & ER protein & $\mathrm{HCC}$ & BA & $\begin{array}{c}\text { cytosolic and } \\
\text { nuclear }\end{array}$ & 9 & 89 & $\begin{array}{c}\text { United States, } \\
\text { Italy }\end{array}$ & 1991 \\
\hline [135] & ER protein & $\mathrm{HCC}$ & BA & $\begin{array}{c}\text { cytosolic and } \\
\text { nuclear }\end{array}$ & 9 & 89 & $\begin{array}{l}\text { United States, } \\
\text { Italy }\end{array}$ & 1991 \\
\hline
\end{tabular}




\begin{tabular}{|c|c|c|c|c|c|c|c|c|}
\hline Reference & Protein /mRNA & $\begin{array}{c}\text { Type of liver } \\
\text { tissue }\end{array}$ & Method & Localization & $\mathrm{n}$ & $\begin{array}{c}\% \\
\text { positive } \\
\text { cases }\end{array}$ & Country & Year \\
\hline$[52]$ & ER protein & $\mathrm{HCC}$ & EIA & cytosolic & 26 & 15 & Spain & 1993 \\
\hline [136] & ER protein & $\mathrm{HCC}$ & $\mathrm{IHC}$ & - & 15 & 0 & Italy & 1993 \\
\hline [136] & ER mRNA & $\mathrm{HCC}$ & ISH & - & 15 & 73 & Italy & 1993 \\
\hline [142] & ER mRNA & $\mathrm{HCC}$ & RT-PCR & - & 14 & 57 & Italy & 1995 \\
\hline$[25]$ & ER protein & $\mathrm{HCC}$ & EIA & cytosolic & 33 & 39 & Germany & 1997 \\
\hline [143] & ER protein & $\mathrm{HCC}$ & $\mathrm{IHC}$ & cytosolic & 71 & 24 & China & 1997 \\
\hline [144] & ER mRNA & $\mathrm{HCC}$ & RT-PCR & - & 40 & 70 & Italy & 1998 \\
\hline [145] & ER mRNA & $\mathrm{HCC}$ & RT-PCR & - & 42 & 60 & Italy & 2003 \\
\hline [146] & ER protein & $\mathrm{HCC}$ & $\mathrm{IHC}$ & $\begin{array}{c}\text { cytosolic and } \\
\text { nuclear }\end{array}$ & 45 & 71 & $\begin{array}{c}\text { United States/ } \\
\text { Koreans }\end{array}$ & 2004 \\
\hline [147] & ER protein & $\mathrm{HCC}$ & $\mathrm{IHC}$ & - & 28 & 39 & China & 2004 \\
\hline [147] & ER mRNA & $\mathrm{HCC}$ & RT-PCR & - & 28 & 89 & China & 2004 \\
\hline [137] & ER mRNA & $\mathrm{HCC}$ & RT-PCR & - & 32 & 100 & Korea & 2006 \\
\hline [148] & ER protein & $\mathrm{HCC}$ & $\mathrm{IHC}$ & - & 66 & 5 & Mexico & 2007 \\
\hline [23] & ER protein & $\mathrm{HCC}$ & $\mathrm{IHC}$ & Nuclear & 31 & 52 & Spain & 2007 \\
\hline
\end{tabular}

ER: Estrogen receptor; HCC: Hepatocellular carcinoma; BA: Binding assay; EIA: Enzyme immunoassay; ISH: In situ hybridization; RT-PCR: Reverse transcriptase-polymerase Chain reaction for ERa wild type; IHC: Immunohistochemistry.

Table 1. Estrogen expression in normal liver and hepatocellular carcinoma tissue samples.

\begin{tabular}{ccccccccc}
\hline Reference & Protein /mRNA & $\begin{array}{c}\text { Type of liver } \\
\text { tissue }\end{array}$ & Method & Localization & $\mathbf{n} \begin{array}{c}\text { \% positive } \\
\text { cases }\end{array}$ & Country & Year \\
\hline [127] & AR protein & Normal & BA & $\begin{array}{c}\text { cytosolic and } \\
\text { nuclear }\end{array}$ & 4 & 0 & $\begin{array}{c}\text { United } \\
\text { Kingdom }\end{array}$ & 1983 \\
\hline$[139]$ & AR protein & Non-cancerous & BA & $\begin{array}{c}\text { cytosolic and } \\
\text { nuclear }\end{array}$ & 6 & 17 & Japan & 1986 \\
\hline$[132]$ & AR protein & Non-cancerous & BA & cytosolic & 17 & 65 & Japan & 1989 \\
\hline$[133]$ & AR protein & Surrounding & & & 21 & 33 & Japan & 1989 \\
\hline$[134]$ & AR protein & Surrounding & BA & cytosolic & 10 & 80 & Japan & 1990 \\
\hline$[135]$ & AR protein & Normal & - & & 9 & 100 & United States, \\
I13] & AR mRNA & Peritumoral & RT-PCR & & 32 & 100 & Korea & 2006 \\
\hline
\end{tabular}




\begin{tabular}{|c|c|c|c|c|c|c|c|c|}
\hline Reference & Protein /mRNA & $\begin{array}{c}\text { Type of liver } \\
\text { tissue }\end{array}$ & Method & Localization & $\mathbf{n}$ & $\begin{array}{c}\% \text { positive } \\
\text { cases }\end{array}$ & Country & Year \\
\hline [127] & AR protein & $\mathrm{HCC}$ & BA & $\begin{array}{c}\text { cytosolic and } \\
\text { nuclear }\end{array}$ & 5 & 100 & $\begin{array}{l}\text { United } \\
\text { Kingdom }\end{array}$ & 1983 \\
\hline [138] & AR protein & $\mathrm{HCC}$ & $\mathrm{IHC}$ & cytosolic & 10 & 50 & Singapore & 1984 \\
\hline [149] & AR protein & $\mathrm{HCC}$ & BA & cytosolic & 19 & 74 & Japan & 1985 \\
\hline$[150]$ & AR protein & $\mathrm{HCC}$ & BA & $\begin{array}{c}\text { cytosolic and } \\
\text { nuclear }\end{array}$ & 5 & 100 & $\begin{array}{l}\text { United } \\
\text { Kingdom }\end{array}$ & 1985 \\
\hline [139] & AR protein & $\mathrm{HCC}$ & BA & $\begin{array}{c}\text { cytosolic and } \\
\text { nuclear }\end{array}$ & 8 & 50 & Japan & 1986 \\
\hline [151] & AR protein & $\mathrm{HCC}$ & BA & cytosolic & 13 & 100 & $\begin{array}{l}\text { United } \\
\text { Kingdom }\end{array}$ & 1988 \\
\hline [132] & AR protein & $\mathrm{HCC}$ & BA & cytosolic & 19 & 37 & Japan & 1989 \\
\hline$[27]$ & AR protein & $\mathrm{HCC}$ & BA & cytosolic & 45 & 69 & Japan & 1989 \\
\hline [134] & AR protein & $\mathrm{HCC}$ & BA & cytosolic & 11 & 64 & Japan & 1990 \\
\hline$[140]$ & AR protein & $\mathrm{HCC}$ & BA & cytosolic & 21 & 86 & Japan & 1991 \\
\hline [135] & AR protein & $\mathrm{HCC}$ & BA & $\begin{array}{c}\text { cytosolic and } \\
\text { nuclear }\end{array}$ & 9 & 100 & $\begin{array}{c}\text { United States, } \\
\text { Italy }\end{array}$ & 1991 \\
\hline [152] & AR protein & $\mathrm{HCC}$ & BA & cytosolic & 5 & 100 & Japan & 1992 \\
\hline [52] & AR protein & $\mathrm{HCC}$ & BA & cytosolic & 26 & 54 & Spain & 1993 \\
\hline [28] & AR protein & $\mathrm{HCC}$ & BA & cytosolic & 43 & 65 & Spain & 1995 \\
\hline [23] & AR protein & $\mathrm{HCC}$ & $\mathrm{IHC}$ & nuclear & 31 & 68 & Spain & 2007 \\
\hline [129] & AR mRNA & $\mathrm{HCC}$ & $\mathrm{ISH}$ & - & 22 & 73 & Italy & 1994 \\
\hline [153] & AR mRNA & $\mathrm{HCC}$ & RT-PCR & - & 38 & 89 & Italy & 2002 \\
\hline [137] & AR mRNA & $\mathrm{HCC}$ & RT-PCR & - & 32 & 100 & Korea & 2006 \\
\hline
\end{tabular}

AR: Androgen receptor; HCC: Hepatocellular carcinoma; BA: Binding assay; ISH: In situ hybridization; RT-PCR: Reverse transcriptase-polymerase Chain reaction; IHC: Immunohistochemistry.

Table 2. Androgen receptor expression in normal liver and hepatocellular carcinoma tissue samples.

Several studies have analyzed the relationship between ER or AR and clinicopathological parameters from HCCs patients and their clinical outcome (Table 3). In general, ER expression was associated with higher tumor aggressiveness and/or worse prognosis in HCC patients [24-26], whereas AR expression was negatively associated with recurrence [27-29]. It is remarkable the finding that the presence of the $\mathrm{ER} \alpha$ variant has been associated with shortened overall survival in patients with resectable HCC $[30,26]$. 


\section{Steroid receptors and hepatitis virus}

It is of special interest the interaction between sex estrogen receptors and viral proteins in hepatitis $B$ virus (HBV) and hepatitis $\mathrm{C}$ virus (HCV)-induced HCC. It has been reported that a $\mathrm{HBV}$ protein $(\mathrm{HBx})$ interacts with $\mathrm{ER} \alpha$. $\mathrm{HBx}$ is a multifunctional protein involved in neoplastic transformation in cultured cells and in HCC induction in transgenic mice. Both $\mathrm{HBx}$ and $\operatorname{vER} \alpha$ (Delta 5 deletion variant of $\operatorname{ER} \alpha$ ) have additive effects on suppressing ER $\alpha$ transactivation [31]. In addition, it was reported that tamoxifen inhibits ER $\alpha$ actions and suppresses $\mathrm{HCV}$ genome replication [32], which may be of potential interest to develop new anti-HCV strategies based on anti-ER drugs. On the other hand, higher serum androgen concentrations or a specific AR gene, which leads to higher AR activities, have also been associated to higher risk in HBV-mediated HCC [33-34]. Likewise, it has been reported that the combination of male gender and HBV infection had a significant synergistic effect on HCC progression [35]. Most recently, Ming-Heng et al. found that hepatic AR increases the HBV viral titer by enhancing HBV RNA transcription through direct binding to the androgen response element near the viral core promoter. This activity forms a positive feedback mechanism with the cooperation of its downstream target, the HBx protein, to promote hepatocarcinogenesis. In addition in these same study administration of a chemical compound that selectively degrades AR, ASC-J9, was able to suppress HCC tumor size in a transgenic HBV mouse model that developed HCC upon exposure to a low dose of N'-N'-diethylnitrosamine (DEN). These results demonstrate that targeting the $\mathrm{AR}$, rather than the androgen, could be developed as a new therapy to battle HBV-induced HCC [36].

\begin{tabular}{|c|c|c|c|c|c|c|}
\hline Reference & $\begin{array}{l}\text { Protein / } \\
\text { mRNA }\end{array}$ & $\begin{array}{l}\text { clinicopathological } \\
\text { parameters }\end{array}$ & Correlation & $n$ & year & country \\
\hline [128] & ER protein & $\begin{array}{c}\text { Serum alpha-fetoprotein, HBV } \\
\text { profile, tumor histology, } \\
\text { carcinoembryonic antigen }\end{array}$ & - & 30 & 1986 & Japan \\
\hline [132] & $\begin{array}{l}\text { ER and } A R \\
\text { protein }\end{array}$ & $\begin{array}{l}\text { Serum alpha-fetoprotein, } \\
\text { Histopathology, HBV markers }\end{array}$ & - & 19 & 1989 & Japan \\
\hline [24] & ER protein & $\begin{array}{l}\text { Sex, age, alcohol } \\
\text { consumption, hepatic } \\
\text { function, other liver disease, } \\
\text { tumor size, hepatic resection, } \\
\text { tumor recurrence, long-term } \\
\text { survival rate }\end{array}$ & $\begin{array}{l}\text { ER- patients showed higher } \\
\text { rate of resection and larger } \\
\text { tumor size }\end{array}$ & 66 & 1990 & Japan \\
\hline [49] & $\begin{array}{l}\text { ER and } A R \\
\text { protein }\end{array}$ & Local recurrence & $\begin{array}{l}\text { AR expression was associated } \\
\text { with intrahepatic recurrence }\end{array}$ & 78 & 1995 & Japan \\
\hline [25] & ER protein & $\begin{array}{l}\text { Survival after curative } \\
\text { resection }\end{array}$ & $\begin{array}{l}\text { ER+ tumor have a negative } \\
\text { effect on patient survival after } \\
\text { curative resection }\end{array}$ & 28 & 1997 & Germany \\
\hline
\end{tabular}




\begin{tabular}{|c|c|c|c|c|c|c|}
\hline Reference & $\begin{array}{l}\text { Protein / } \\
\text { mRNA }\end{array}$ & $\begin{array}{l}\text { clinicopathological } \\
\text { parameters }\end{array}$ & Correlation & n & year & country \\
\hline [26] & ER mRNA & Survival & $\begin{array}{l}\text { Wild type ERs tumors showed } \\
\text { long survival in patients }\end{array}$ & 96 & 2000 & Italy \\
\hline [132] & AR protein & Recurrence and survival rate & $\begin{array}{l}\text { AR+ patients showed higher } \\
\text { recurrence rates. } \\
\text { AR- patients showed better } \\
\text { survival rates. }\end{array}$ & 45 & 1989 & Japan \\
\hline [28] & AR protein & $\begin{array}{l}\text { Tumor size and tumor } \\
\text { recurrence }\end{array}$ & $\begin{array}{l}\text { AR expression correlated with } \\
\text { smaller tumor size. Higher } \\
\text { tumor recurrence in AR+ } \\
\text { surrounding tissues. }\end{array}$ & 43 & 1995 & Spain \\
\hline [29] & AR protein & Tumor size and survival time & $\begin{array}{l}\text { AR+ tumor correlated with } \\
\text { higher tumor size and lower } \\
\text { survival rates. }\end{array}$ & 32 & 1998 & China \\
\hline
\end{tabular}

ER: Estrogen receptor; AR: Androgen receptor

Table 3. Relationship between estrogen or androgen receptors with clinicopathological parameters and clinical outcome of patients with HCC.

\section{Endocrine therapy in hepatocellular carcinoma}

Considering both the epidemiologic and the experimental data supporting the sex steroids influence in growth and progression from HCCs, different clinical studies analyzed if endocrine therapy could be interesting in advanced disease. Table 4 gives details of some of these studies. Trials using several agents, such as the anti-estrogen tamoxifen, megestrol acetate, progestin, the gonadotropin releasing hormone $(\mathrm{GnRH})$ agonist leuprorelin and the antiandrogen flutamide have been uniformly disappointing [37-40]. At present, experts have concluded that hormonal manipulation should not be a part of the current management of patients with HCC [41-42]. However, it is possible that the rational design of an endocrine therapy requires a more complete understanding of the role of sex hormones in the tumorigenic process and how hormones and organ systems interact during this process [18], in addition to careful selection of the new studies patient populations, since patient stratification based on gender may uncover signals of activity of hormonal therapy in these settings. Notably, it has been shown that the anti-estrogens tamoxifen and raloxifene, behave differently in different tissues, producing estrogen-agonist activity in one tissue while behaving as an antagonist in another [43-44]. In addition, in vitro studies in the liver cell line Hep3B, indicate that raloxifene induces the insulin-like growth factor (IGF-I) gene transcription, whereas estradiol or tamoxifen inhibits it [45]. On the other hand, the lack of hormone efficacy in these clinical studies, in terms of tumor growth and survival, could be due to either a low expression of ER or AR in HCC or to mutated receptors expression. Therefore, further studies will be necessary to 
improve patient selection on the basis of gender, ER tumor expression and their functional status. With regard to this latter aspect, considering that PgR is an estrogen inducible protein, it led us to consider that this steroid receptor could be a possible marker of ER functional status in HCC, to select candidate patients to an anti-estrogenic therapy. In addition, we demonstrated that PgR expression have a prognostic implication in patients with resected HCCs, being a factor associated with better prognostic [23], which is a clinical finding previously demonstrated in breast cancer [46-47]. This finding is very important considering also our reported positive association between PgR expression and HCV infection [23], which represents an increasing aetiology of HCC in our patient's population [3].

Several data suggest that blocking AR may be interesting in HCC therapy. Studies in animal models suggest that increased hepatic AR expression correlated with accelerated tumor development [48], or even AR expression was associated with intrahepatic recurrence in HCC [49]. However, AR expression has also been reported to be associated to small tumor size, but not with a higher rate of recurrence [28]. More recent data indicate that suppression of androgen or AR signals also led to an increase in the number of infiltrating cells, such as macrophages as well as B or T-cells [50], which shows diverse and important roles in the promotion of HCC tumorigenicity [51]. Although there is few data on the effect of antiandrogens in HCC patients, it has been suggested that anti-androgen therapy may have some benefit in patients with androgen-positive tumors [52]. Likewise, recently it has been reported that a multicenter trial with anti-androgens in HCC male patients, has been interrupted because of digestive side effects [39]. Nevertheless, further studies will be necessary to assess whether AR status may be a useful marker to select more accurately candidate patients to further anti-androgenic therapies. Notably, it has been reported that expression of androgeninduced proteins, such as apolipoprotein D or Zinc-alpha2-glycoprotein, is associated with poor prognosis in HCC.

Apolipoprotein D (ApoD) is an androgen-induced protein increased in both prostate and breast cancer cells [53-55]. A report of Utsunomiya et al. showed that low ApoD expression correlated significantly with less-differentiated HCCs and therefore with a worse prognosis of patients [56]. However, we did not found any relationship between ApoD expression and the hormonal receptor status in HCC [23]. Nevertheless, further studies will be also necessary in order to assess the possible value of $\mathrm{ApoD}$ as a biological marker of androgen response and/ or other hormonal pathways in HCC. Thus, with regard to this latter aspect, although ApoD is an androgen-regulated protein, it can also been induced by other hormonal steroids or substances such as glucocorticoids, retinoic acid or 1,25-dihydroxyvitamin $\mathrm{D}_{3}$, that might be involved in the regulation of this ApoD in human tumors [54,57-58]. This is relevant since it has been described that both retinoid and glucocorticoid receptors have been also detected in HCC [59-60], and that preliminary data show that retinoids are considered of clinical interest as cancer chemotherapeutic agents in advanced HCC [61].

Zinc-alpha2-glycoprotein (ZA2G) is also an androgen-induced protein increased in breast cancer [58,62]. Recently, ZA2G expression was found to be decreased in HCC tissues at both mRNA and protein levels. Moreover, low expression of ZA2G was notably more prevalent in 


\begin{tabular}{|c|c|c|c|c|c|c|}
\hline $\begin{array}{l}\text { Hormone } \\
\text { Receptor/ } \\
\text { mRNA }\end{array}$ & $\begin{array}{l}\text { Valuation } \\
\text { parameters }\end{array}$ & Treatment & n & Clinical outcomes & Year & Reference \\
\hline $\begin{array}{l}\text { ER (previous } \\
\text { patient } \\
\text { group) }\end{array}$ & Tumor growth & Progestin & 5 & Tumor regression in 2 & 1982 & [124] \\
\hline NA & $\begin{array}{l}\text { Anti-tumoral } \\
\text { effect. } \\
\text { Survival. }\end{array}$ & $\begin{array}{l}\text { Tamoxifen } 20 \text { mg } \\
\text { twice daily. }\end{array}$ & 33 & $\begin{array}{l}\text { No effect on the tumor, } \\
\text { in } 8 \text { remained stable } \\
\text { between } 5 \text { and } 13 \\
\text { months. Prolonged } \\
\text { survival in } 4 \text { patients } \\
\text { (over } 18 \text { months). }\end{array}$ & 1990 & [154] \\
\hline NA & $\begin{array}{l}\text { Anti-tumoral } \\
\text { effect. } \\
\text { Survival. }\end{array}$ & $\begin{array}{l}\text { Tamoxifen } \\
20 \text { mg daily. }\end{array}$ & $\begin{array}{c}120 \\
(\text { placebo }= \\
62)\end{array}$ & $\begin{array}{l}\text { No effect on the tumor. } \\
\text { No effect on survival. }\end{array}$ & 1995 & [155] \\
\hline $\begin{array}{l}\text { Wild type and } \\
\text { variant ER } \\
\text { RNA m }\end{array}$ & Tumor growth. & $\begin{array}{l}\text { Tamoxifen } \\
80 \text { mg daily in } \\
\text { patients with wild-ERs } \\
\text { or megestrol } \\
160 \text { mg daily in } \\
\text { patients with variant } \\
\text { ERs. }\end{array}$ & $\begin{array}{l}8 \text { patients, } 4 \\
\text { with wild ERs } \\
\text { and } 4 \text { with } \\
\text { variant ERs. }\end{array}$ & $\begin{array}{l}\text { Tumor regression to half } \\
\text { size in patients with wild } \\
\text { type ERs following } \\
\text { tamoxifen treatment. } \\
\text { Megestrol slowed down } \\
\text { tumor growth in tumors } \\
\text { with variant ERs. }\end{array}$ & 1996 & [30] \\
\hline ER y $P R$ & Survival. & Tamoxifen. & $\begin{array}{c}119 \\
(\text { placebo }= \\
58)\end{array}$ & $\begin{array}{l}\text { No effects on survival, } \\
\text { regardless of the type of } \\
\text { receptor expressed. }\end{array}$ & 2000 & [156] \\
\hline $\begin{array}{l}\text { Variant ER } \\
\text { mRNA. }\end{array}$ & $\begin{array}{l}\text { Tumor growth. } \\
\text { Survival. }\end{array}$ & $\begin{array}{l}\text { Megestrol } \\
160 \text { mg daily. }\end{array}$ & $\begin{array}{l}45 \text { (placebo = } \\
\text { 24). }\end{array}$ & $\begin{array}{l}\text { Significantly slowed } \\
\text { down tumor growth and } \\
=\text { improved survival in } \\
\text { treated patients than } \\
\text { placebo group. }\end{array}$ & 2001 & [157] \\
\hline NA & $\begin{array}{l}\text { Survival. } \\
\text { Quality of life. }\end{array}$ & $\begin{array}{l}\text { Tamoxifen } \\
120 \text { mg or } 60 \text { mg } \\
\text { daily. }\end{array}$ & 329 & $\begin{array}{l}\text { No effect on survival or } \\
\text { on quality of life. } \\
\text { Deleterious effects with } \\
\text { the higher dose. }\end{array}$ & 2002 & [158] \\
\hline
\end{tabular}

$E R=$ Estrogen receptor. NA=information not available. $P R=$ Progesterone Receptor.

Table 4. Results of hormonal treatment in hepatocellular carcinoma

patients with poor tumor differentiation, advanced liver cirrhosis, high serum alpha fetoprotein (AFP) level and shorter survival time. These results suggest that ZA2G may be a promising novel prognostic biomarker for HCC [63], and advocate for the need for validation studies. 
Recent data indicates that estrogens attenuate tumor progression in HCC in vivo by reducing tumor cell invasion, arresting cell cycle progression, and promoting apoptosis, which is characterized by an increased expression of cleaved caspase-3, and by a decrease in the expression of Proliferating Cell Nuclear Antigen (PCNA), cyclin A, cyclin D1, Bcl-2, and matrix metalloproteases (MMP) 2 and 9 [64]. It is relevant the data indicating that steroid hormones, such as estrogens, may inhibit MMPs in several experimental models [65-67]. This may be of great importance due to MMPs are proteolytic enzymes which participate in the degradation of the stromal connective tissue and basement membrane component, therefore facilitating tumor invasion and metastasis. Here, we show a negative relationship between ER expression and MMP2, MMP-9 or MMP-11 expression in HCC (Figure 1).

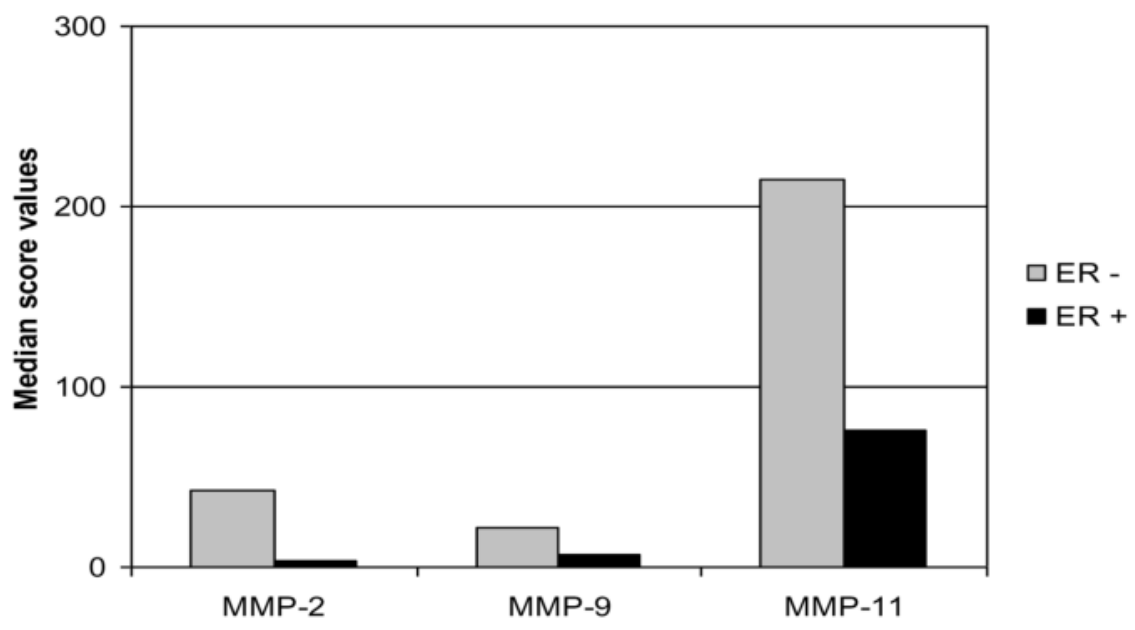

Figure 1. Relationship between ER expression and median score values of MMP2, MMP-9 or MMP-11 expression in HCC.

\section{Metalloproteases and their inhibitors}

Degradation of the stromal connective tissue and basement membrane components are key elements in tumor invasion and metastasis. Some components of the extracelluar matrix, particularly interstitial collagens, are very resistant to proteolytic attacks, being degraded only by matrix metalloproteases (MMPs) [68].

The human MMP family currently consists of 28 members of homologous zinc-dependent endopeptidases, which can be divided into eight structural classes or, based on their substrate specificity and primary structure, into the more familiar subgroups of collagenases (MMP-1, -8 and -13), gelatinases (MMP-2 and -9), stromelysins (MMP-3, -10, -11), membrane-associated MMPs (MMP-14, -15, -16, -17, -23, -24, -25) and other novel MMPs [69-71]. MMPs are synthe- 
sized as inactive zymogens, which are then activated predominantly pericellularly by other MMPs or by serine-proteases. MMPs' activity is specifically inhibited by the so-called tissue inhibitors of metalloproteases (TIMPs). Currently, four different TIMPs are known to exist: TIMP-1, -2, -3 and -4. In addition, there are other two additional aspects conferring relevance to this enzymatic system in cancer biology. First, MMPs are able to impact on tumor cell behavior in vivo as a consequence of their ability to cleave growth factors, cell surface receptors, cell adhesion molecules, or chemokines/cytoquines [72-77]. Furthermore, by cleaving proapoptotic factors, MMPs may induce a more aggressive phenotype via generation of apoptotic resistant cells [78]. MMPs may also regulate angiogenesis in cancer, both positively through their ability to mobilize or activate proangiogenic factors [79-80], and negatively via generation of angiogenesis inhibitors, such as angiostatin and endostatin, cleaved from large protein precursors [81-83]. Second, it is now assumed that TIMPs are multifactorial proteins also involved in the induction of proliferation and the inhibition of apoptosis [84-85].

Previous studies have shown the expression of several MMPs in HCC [86-100]. These findings have a great interest because HCC is characterized by a disposition for vascular invasion and high metastatic potential, thus leading to high incidence of early postoperative recurrence and poor survival [101-102]. Although there is no basal membrane in the liver, HCC cancer cells grow surrounded by extracellular matrix proteins secreted as a consequence of cirrhosis, and therefore proteolytic activity is required to allow HCC cells to penetrate and cross over such tissue boundaries [103]. In fact, several studies have suggested the significance of some MMPs in the malignant behavior of HCC, such as MMP-2 [86-93], MMP-7 [88,94], MMP-9 [95-97,91,93,104], MMP-12 [105] or MMP-14 (MT1-MMP) [98,91,99-100]. In these studies, MMPs were associated with several parameters indicative of tumor aggressiveness and poor prognosis, although the cellular type expressing each factor (tumor cell and/or peritumor stromal cell) was not specifically considered.

There are few available data referring to the integrated expression of these factors in relation with HCC. In this context, we have described new findings about MMPs and TIMPs expressions in HCC, together with an important expression by tumor stromal cells, as well as their clinical relevance. It is known that MMPs expression in neoplastic tissues is high due to regulation, in a paracrine manner, by growth factors and cytokines secreted by either tumor or stromal cells [106]. Nevertheless, high MMPs and TIMPs expression by HCCs tissues may be also due to the interplay between transformed cells and their microenvironment, particularly the surrounding extracellular matrix. In human livers, fibrogenesis underlies the development of HCCs in at least $90 \%$ of cases [107], and HCC is typically surrounded by a fibrous capsule at an early stage [108]. In addition, several studies have shown that some MMPs (MMP-1, -2, -9 and -13) and TIMPs (TIMP-1 and -2) are involved in the liver fibrosis processes [90,109-112]. It has been demonstrated that extracellular matrix deposition induces overexpression of MMPs and TIMPs, such as MMP-2, secreted by human mesenchymal cells but also by hepatoma cells [87].

Recently we reported that immunostaining for MMPs and TIMPs was localized predominantly in tumor cells, but also in peritumor stromal cells in a significant percentage of cases. However, 
we found no stromal expression of MMPs or TIMPs in normal liver samples [113]. We also found a positive and noteworthy association between MMP-1 expression by fibroblasts or by mononuclear inflammatory cells (MICs) and a larger tumor size. In addition, our data showed that MMP-1 expression by stromal fibroblasts, as well as the expression of MMP-13, TIMP-1 and 2, by MICs, were significantly associated with a shorter overall survival (Figure 2) [113].
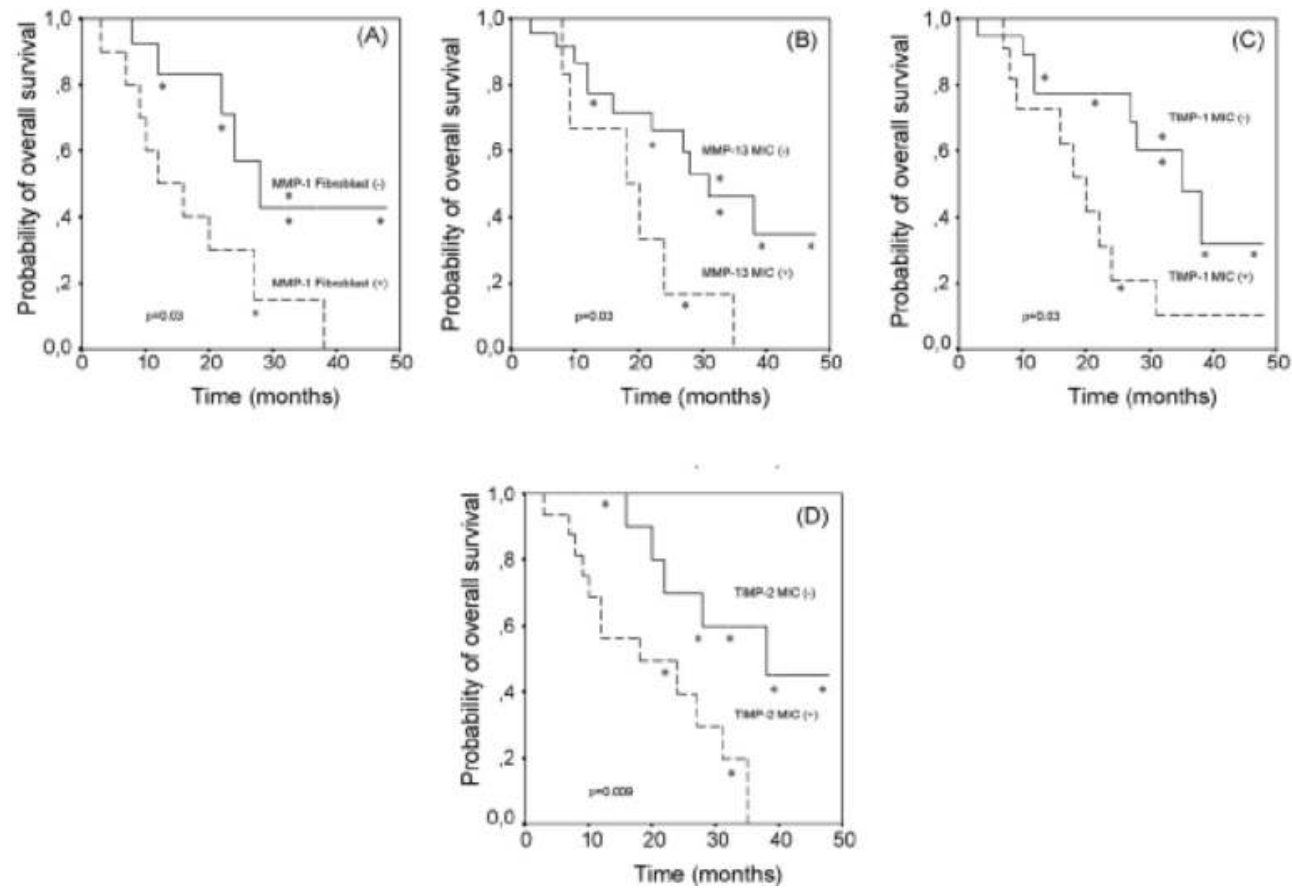

Figure 2. Kaplan-Meier survival curves as function of the expression by fibroblasts cells of MMP-1 (A); expression by MIC of MMP-13 (B), TIMP-1 (C) and TIMP-2 (D).

There are discrepancies between different studies regarding the prognostic significance of several of these factors in HCC, such as MMP-9 and MMP-2 expression in stromal compartments $[113,93]$. Nevertheless, it is worth considering the existence of possible differences in MMPs or TIMPs expression between different patient's populations. Thus, for example, in Asian countries HCC originates more frequently in healthy liver tissues, with less incidence of cirrhosis, than in Europe, whereas in the Mediterranean area as well as in the North American countries liver HCC only develops in chronically injured livers, where altered turn-over and increased deposition of ECM proteins has been described. In a such environment, upregulation of MMPs and TIMPs has been reported and it is possible for them to play an important role in the rearrangement of the liver tissue architecture an aspect that could influence the different expression pattern of MMPs and TIMPs in stromal HCC cells [110,114]. 
On the other hand, a decrease on TIMP-2 and -3 expression has been reported to be associated with invasion and metastases in HCC [115-116]. Certainly, if TIMPs inhibit MMPs in vivo, it should be expected that high levels of these inhibitors would prevent tumor progression and thus to be related with good outcome in cancer patients. However, TIMPs are multifunctional proteins that in addition to its MMP-inhibitory effect also shown distinct tumor-stimulatory functions, such as the induction of proliferation and the inhibition of apoptosis [84]. Thus, it is of note that TIMP-1 and -2 expressions by stromal cells were associated with shortened overall survival[113]. Accordingly, it has been reported that TIMP-1 overexpression leads to an increase of hepatoma cells migration [117], and also that it is associated with invasion and metastases in HCC $[115,117]$.

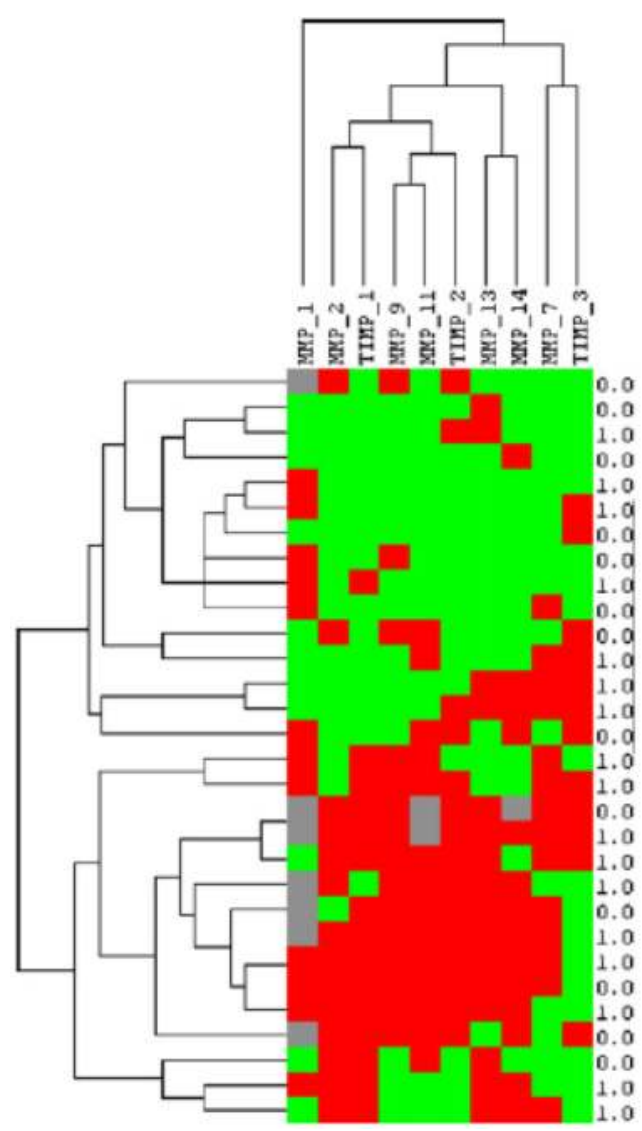

Figure 3. Graphical representation of two-dimensional unsupervised hierarchical clustering results on immunohistochemistry expression (score values) profile in 10 proteins (MMPs and TIMPs) in 30 samples of HCC tissue. Rows: tumor samples; columns: MMPs and TIMPs. Protein expressions are depicted according to a color scale: red: positive staining; green: negative staining; gray: missing data. At right bank of the figure is represented the overall survival status for each patient ( 0 , alive; 1 , death due tumor progression). 
The unsupervised hierarchical cluster analysis of MMPs/TIMPs expressions in HCCs led us to identify 2 well-defined clusters of cases (Figure 3): one with low expression of MMPs and TIMPs (Group 1), and another with high expression of these factors (Group 2). This classification could have biological interest in order to identify patient candidates to new therapies based on enzymatic MMP inhibition. With regard to this, although there are no published data about use of MMP inhibitors in HCC, recently it has been reported that decreased MMP activity mediated by statins reduced progression and limits metastatic diffusion of established HCC [118]. Likewise, it was demonstrated that blocking the tumor-related glycoprotein HAb18G/ CD147 by gene silence in HCC cells or with HA18 monoclonal antibody, resulted in a suppressive effect on MMP secretion and cell invasion [119]. More recent studies have shown an antimetastatic effect of Norcantharidin on HCC by transcriptional inhibition of MMP-9 [120], as well as a metastasis inhibition of HCC cells due to down-regulation of Osteopontin via a mechanism involving MMP-2 and urinary plasminogen activator (uPA) [121].

\section{Conclusion}

In summary, we consider that expression analysis of steroid hormone receptors, MMPs and TIMPs, contributes to a better knowledge in the biological characterization of HCC and highlights the need for further studies exploring new therapeutic targets for this common tumor.

\section{Author details}

Noemí Eiró, Belen Fernandez-Garcia, Antonio Altadill, Luis O. González and Francisco J. Vizoso*

*Address all correspondence to: fjvizoso@terra.es

Unidad de Investigación. Fundación Hospital de Jove. Gijón, Asturias, Spain

\section{References}

[1] Parkin DM, Bray F, Ferlay J, Pisani P (2005) Global cancer statistics, 2002. CA Cancer J Clin 55 (2):74-108. [PubMed: 15761078]

[2] Nordenstedt H, White DL, El-Serag HB (2010) The changing pattern of epidemiology in hepatocellular carcinoma. Dig Liver Dis 42 Suppl 3:S206-214. [PubMed: 20547305]

[3] El-Serag HB, Mason AC (1999) Rising incidence of hepatocellular carcinoma in the United States. N Engl J Med 340 (10):745-750. [PubMed: 10072408] 
[4] Poon RT, Ng IO, Fan ST, Lai EC, Lo CM, Liu CL, Wong J (2001) Clinicopathologic features of long-term survivors and disease-free survivors after resection of hepatocellular carcinoma: a study of a prospective cohort. J Clin Oncol 19 (12):3037-3044. [PubMed: 11408499]

[5] Kato A, Miyazaki M, Ambiru S, Yoshitomi H, Ito H, Nakagawa K, Shimizu H, Yokosuka O, Nakajima N (2001) Multidrug resistance gene (MDR-1) expression as a useful prognostic factor in patients with human hepatocellular carcinoma after surgical resection. J Surg Oncol 78 (2):110-115. [PubMed: 11579388]

[6] Yu MC, Yuan JM (2004) Environmental factors and risk for hepatocellular carcinoma. Gastroenterology 127 (5 Suppl 1):S72-78. [PubMed: 15508106]

[7] Marrero JA, Fontana RJ, Fu S, Conjeevaram HS, Su GL, Lok AS (2005) Alcohol, tobacco and obesity are synergistic risk factors for hepatocellular carcinoma. J Hepatol 42 (2):218-224. [PubMed: 15664247]

[8] Ohishi W, Fujiwara S, Cologne JB, Suzuki G, Akahoshi M, Nishi N, Takahashi I, Chayama K (2008) Risk factors for hepatocellular carcinoma in a Japanese population: a nested case-control study. Cancer Epidemiol Biomarkers Prev 17 (4):846-854. [PubMed: 18398026]

[9] Shimizu I, Kohno N, Tamaki K, Shono M, Huang HW, He JH, Yao DF (2007) Female hepatology: favorable role of estrogen in chronic liver disease with hepatitis B virus infection. World J Gastroenterol 13 (32):4295-4305. [PubMed: 17708600]

[10] Shimizu I (2003) Impact of oestrogens on the progression of liver disease. Liver Int 23 (1):63-69. [PubMed: 12640729]

[11] Fechner RE (1977) Benign hepatic lesions and orally administered contraceptives. A report of seven cases and a critical analysis of the literature. Hum Pathol 8 (3): 255-268. [PubMed: 192659]

[12] Vana J, Murphy GP, Aronoff BL, Baker HW (1977) Primary liver tumors and oral contraceptives. Results of a survey. JAMA 238 (20):2154-2158. [PubMed: 199752]

[13] Kemp CJ, Leary CN, Drinkwater NR (1989) Promotion of murine hepatocarcinogenesis by testosterone is androgen receptor-dependent but not cell autonomous. Proc Natl Acad Sci U S A 86 (19):7505-7509. [PubMed: 2798421]

[14] Poole TM, Drinkwater NR (1995) Hormonal and genetic interactions in murine hepatocarcinogenesis. Prog Clin Biol Res 391:187-194. [PubMed: 8532716]

[15] Nakatani T, Roy G, Fujimoto N, Asahara T, Ito A (2001) Sex hormone dependency of diethylnitrosamine-induced liver tumors in mice and chemoprevention by leuprorelin. Jpn J Cancer Res 92 (3):249-256. [PubMed: 11267934]

[16] Yamamoto R, Iishi H, Tatsuta M, Yamamoto T, Koike K, Kanda Y, Miyake A, Tsuji M, Terada N (1995) Correlation between serum prolactin levels and hepatocellular 
tumorigenesis induced by 3'-methyl-4-dimethylaminoazobenzene in mice. Br J Cancer 72 (1):17-21. [PubMed: 7599048]

[17] Ormandy CJ, Binart N, Helloco C, Kelly PA (1998) Mouse prolactin receptor gene: genomic organization reveals alternative promoter usage and generation of isoforms via alternative 3'-exon splicing. DNA Cell Biol 17 (9):761-770. [PubMed: 9778035]

[18] Bigsby RM, Caperell-Grant A (2011) The role for estrogen receptor-alpha and prolactin receptor in sex-dependent DEN-induced liver tumorigenesis. Carcinogenesis 32 (8):1162-1166. [PubMed: 21606321]

[19] Pettersson K, Gustafsson JA (2001) Role of estrogen receptor beta in estrogen action. Annu Rev Physiol 63:165-192. [PubMed: 11181953]

[20] Gavrilova-Jordan LP, Price TM (2007) Actions of steroids in mitochondria. Semin Reprod Med 25 (3):154-164. [PubMed: 17447205]

[21] Boonyaratanakornkit V, Edwards DP (2007) Receptor mechanisms mediating nongenomic actions of sex steroids. Semin Reprod Med 25 (3):139-153. [PubMed: 17447204]

[22] Kalra M, Mayes J, Assefa S, Kaul AK, Kaul R (2008) Role of sex steroid receptors in pathobiology of hepatocellular carcinoma. World J Gastroenterol 14 (39):5945-5961. [PubMed: 18932272]

[23] Vizoso FJ, Rodriguez M, Altadill A, Gonzalez-Dieguez ML, Linares A, Gonzalez LO, Junquera S, Fresno-Forcelledo F, Corte MD, Rodrigo L (2007) Liver expression of steroid hormones and Apolipoprotein D receptors in hepatocellular carcinoma. World J Gastroenterol 13 (23):3221-3227. [PubMed: 17589901]

[24] Nagasue N, Kohno H, Chang YC, Yamanoi A, Nakamura T, Yukaya H, Hayashi T (1990) Clinicopathologic comparisons between estrogen receptor-positive and -negative hepatocellular carcinomas. Ann Surg 212 (2):150-154. [PubMed: 2165386]

[25] Jonas S, Bechstein WO, Heinze T, Kling N, Lobeck H, Tullius SG, Steinmueller T, Neuhaus P (1997) Female sex hormone receptor status in advanced hepatocellular carcinoma and outcome after surgical resection. Surgery 121 (4):456-461. [PubMed: 9122877]

[26] Villa E, Moles A, Ferretti I, Buttafoco P, Grottola A, Del Buono M, De Santis M, Manenti F (2000) Natural history of inoperable hepatocellular carcinoma: estrogen receptors' status in the tumor is the strongest prognostic factor for survival. Hepatology 32 (2):233-238. [PubMed: 10915729]

[27] Nagasue N, Chang YC, Hayashi T, Galizia G, Kohno H, Nakamura T, Yukaya H (1989) Androgen receptor in hepatocellular carcinoma as a prognostic factor after hepatic resection. Ann Surg 209 (4):424-427. [PubMed: 2539062]

[28] Boix L, Castells A, Bruix J, Sole M, Bru C, Fuster J, Rivera F, Rodes J (1995) Androgen receptors in hepatocellular carcinoma and surrounding liver: relationship with tu- 
mor size and recurrence rate after surgical resection. J Hepatol 22 (6):616-622. [PubMed: 7560855]

[29] Zhang X, He L, Lu Y, Liu M, Huang X (1998) Androgen receptor in primary hepatocellular carcinoma and its clinical significance. Chin Med J (Engl) 111 (12):1083-1086. [PubMed: 11263369]

[30] Villa E, Dugani A, Fantoni E, Camellini L, Buttafoco P, Grottola A, Pompei G, De Santis M, Ferrari A, Manenti F (1996) Type of estrogen receptor determines response to antiestrogen therapy. Cancer Res 56 (17):3883-3885. [PubMed: 8752151]

[31] Han J, Ding L, Yuan B, Yang X, Wang X, Li J, Lu Q, Huang C, Ye Q (2006) Hepatitis B virus $X$ protein and the estrogen receptor variant lacking exon 5 inhibit estrogen receptor signaling in hepatoma cells. Nucleic Acids Res 34 (10):3095-3106. [PubMed: 16757575]

[32] Watashi K, Inoue D, Hijikata M, Goto K, Aly HH, Shimotohno K (2007) Anti-hepatitis $C$ virus activity of tamoxifen reveals the functional association of estrogen receptor with viral RNA polymerase NS5B. J Biol Chem 282 (45):32765-32772. [PubMed: 17704057]

[33] Yu MW, Yang YC, Yang SY, Cheng SW, Liaw YF, Lin SM, Chen CJ (2001) Hormonal markers and hepatitis B virus-related hepatocellular carcinoma risk: a nested casecontrol study among men. J Natl Cancer Inst 93 (21):1644-1651. [PubMed: 11698569]

[34] Yu MW, Cheng SW, Lin MW, Yang SY, Liaw YF, Chang HC, Hsiao TJ, Lin SM, Lee SD, Chen PJ, Liu CJ, Chen CJ (2000) Androgen-receptor gene CAG repeats, plasma testosterone levels, and risk of hepatitis B-related hepatocellular carcinoma. J Natl Cancer Inst 92 (24):2023-2028. [PubMed: 11121465]

[35] Wang N, Zheng Y, Yu X, Lin W, Chen Y, Jiang Q (2009) Sex-modified effect of hepatitis $B$ virus infection on mortality from primary liver cancer. Am J Epidemiol 169 (8): 990-995. [PubMed: 19224979]

[36] Wu MH, Ma WL, Hsu CL, Chen YL, Ou JH, Ryan CK, Hung YC, Yeh S, Chang C (2010) Androgen receptor promotes hepatitis B virus-induced hepatocarcinogenesis through modulation of hepatitis B virus RNA transcription. Sci Transl Med 2 (32): 32ra35. [PubMed: 20484730]

[37] Colleoni M, Nelli P, Vicario G, Mastropasqua G, Manente P (1995) Megestrol acetate in unresectable hepatocellular carcinoma. Tumori 81 (5):351-353. [PubMed: 8804452]

[38] Chao Y, Chan WK, Huang YS, Teng HC, Wang SS, Lui WY, Whang-Peng J, Lee SD (1996) Phase II study of flutamide in the treatment of hepatocellular carcinoma. Cancer 77 (4):635-639. [PubMed: 8616754]

[39] Randomized trial of leuprorelin and flutamide in male patients with hepatocellular carcinoma treated with tamoxifen (2004). Hepatology 40 (6):1361-1369. [PubMed: 15565568] 
[40] Ruden DM, Xiao L, Garfinkel MD, Lu X (2005) Hsp90 and environmental impacts on epigenetic states: a model for the trans-generational effects of diethylstibesterol on uterine development and cancer. Hum Mol Genet 14 Spec No 1:R149-155. [PubMed: 15809267]

[41] Di Maio M, De Maio E, Morabito A, D'Aniello R, De Feo G, Gallo C, Perrone F (2006) Hormonal treatment of human hepatocellular carcinoma. Ann N Y Acad Sci 1089:252-261. [PubMed: 17261772]

[42] Di Maio M, Daniele B, Pignata S, Gallo C, De Maio E, Morabito A, Piccirillo MC, Perrone $\mathrm{F}$ (2008) Is human hepatocellular carcinoma a hormone-responsive tumor? World J Gastroenterol 14 (11):1682-1689. [PubMed: 18350599]

[43] Bryant HU, Dere WH (1998) Selective estrogen receptor modulators: an alternative to hormone replacement therapy. Proc Soc Exp Biol Med 217 (1):45-52. [PubMed: 9421206]

[44] Grese TA, Dodge JA (1998) Selective estrogen receptor modulators (SERMs). Curr Pharm Des 4 (1):71-92. [PubMed: 10197034]

[45] Fournier B, Gutzwiller S, Dittmar T, Matthias G, Steenbergh P, Matthias P (2001) Estrogen receptor (ER)-alpha, but not ER-beta, mediates regulation of the insulin-like growth factor I gene by antiestrogens. J Biol Chem 276 (38):35444-35449. [PubMed: 11457856]

[46] Stendahl M, Ryden L, Nordenskjold B, Jonsson PE, Landberg G, Jirstrom K (2006) High progesterone receptor expression correlates to the effect of adjuvant tamoxifen in premenopausal breast cancer patients. Clin Cancer Res 12 (15):4614-4618. [PubMed: 16899609]

[47] Punglia RS, Kuntz KM, Winer EP, Weeks JC, Burstein HJ (2006) The impact of tumor progesterone receptor status on optimal adjuvant endocrine therapy for postmenopausal patients with early-stage breast cancer: a decision analysis. Cancer 106 (12): 2576-2582. [PubMed: 16703595]

[48] Eagon PK, Elm MS, Epley MJ, Shinozuka H, Rao KN (1996) Sex steroid metabolism and receptor status in hepatic hyperplasia and cancer in rats. Gastroenterology 110 (4):1199-1207. [PubMed: 8613010]

[49] Nagasue N, Yu L, Yukaya H, Kohno H, Nakamura T (1995) Androgen and oestrogen receptors in hepatocellular carcinoma and surrounding liver parenchyma: impact on intrahepatic recurrence after hepatic resection. Br J Surg 82 (4):542-547. [PubMed: 7613907]

[50] Mercader M, Bodner BK, Moser MT, Kwon PS, Park ES, Manecke RG, Ellis TM, Wojcik EM, Yang D, Flanigan RC, Waters WB, Kast WM, Kwon ED (2001) T cell infiltration of the prostate induced by androgen withdrawal in patients with prostate cancer. Proc Natl Acad Sci U S A 98 (25):14565-14570. [PubMed: 11734652] 
[51] Berasain C, Castillo J, Perugorria MJ, Latasa MU, Prieto J, Avila MA (2009) Inflammation and liver cancer: new molecular links. Ann N Y Acad Sci 1155:206-221. [PubMed: 19250206]

[52] Boix L, Bruix J, Castells A, Fuster J, Bru C, Visa J, Rivera F, Rodes J (1993) Sex hormone receptors in hepatocellular carcinoma. Is there a rationale for hormonal treatment? J Hepatol 17 (2):187-191. [PubMed: 8383159]

[53] Simard J, Dauvois S, Haagensen DE, Levesque C, Merand Y, Labrie F (1990) Regulation of progesterone-binding breast cyst protein GCDFP-24 secretion by estrogens and androgens in human breast cancer cells: a new marker of steroid action in breast cancer. Endocrinology 126 (6):3223-3231. [PubMed: 2351114]

[54] Simard J, de Launoit Y, Haagensen DE, Labrie F (1992) Additive stimulatory action of glucocorticoids and androgens on basal and estrogen-repressed apolipoprotein-D messenger ribonucleic acid levels and secretion in human breast cancer cells. Endocrinology 130 (3):1115-1121. [PubMed: 1537279]

[55] Sugimoto K, Simard J, Haagensen DE, Labrie F (1994) Inverse relationships between cell proliferation and basal or androgen-stimulated apolipoprotein D secretion in LNCaP human prostate cancer cells. J Steroid Biochem Mol Biol 51 (3-4):167-174. [PubMed: 7526888]

[56] Utsunomiya T, Ogawa K, Yoshinaga K, Ohta M, Yamashita K, Mimori K, Inoue H, Ezaki T, Yoshikawa Y, Mori M (2005) Clinicopathologic and prognostic values of apolipoprotein D alterations in hepatocellular carcinoma. Int J Cancer 116 (1): 105-109. [PubMed: 15756681]

[57] Lopez-Boado YS, Tolivia J, Lopez-Otin C (1994) Apolipoprotein D gene induction by retinoic acid is concomitant with growth arrest and cell differentiation in human breast cancer cells. J Biol Chem 269 (43):26871-26878. [PubMed: 7929425]

[58] Lopez-Boado YS, Diez-Itza I, Tolivia J, Lopez-Otin C (1994) Glucocorticoids and androgens up-regulate the $\mathrm{Zn}$-alpha 2-glycoprotein messenger RNA in human breast cancer cells. Breast Cancer Res Treat 29 (3):247-258. [PubMed: 8049458]

[59] P'Eng F K, Lui WY, Chang TJ, Kao HL, Wu LH, Liu TY, Chi CW (1988) Glucocorticoid receptors in hepatocellular carcinoma and adjacent liver tissue. Cancer 62 (10): 2134-2138. [PubMed: 2460210]

[60] Sano K, Takayama T, Murakami K, Saiki I, Makuuchi M (2003) Overexpression of retinoic acid receptor alpha in hepatocellular carcinoma. Clin Cancer Res 9 (10 Pt 1): 3679-3683. [PubMed: 14506158]

[61] Clerici C, Castellani D, Russo G, Fiorucci S, Sabatino G, Giuliano V, Gentili G, Morelli O, Raffo P, Baldoni M, Morelli A, Toma S (2004) Treatment with all-trans retinoic acid plus tamoxifen and vitamin $\mathrm{E}$ in advanced hepatocellular carcinoma. Anticancer Res 24 (2C):1255-1260. [PubMed: 15154656] 
[62] Diez-Itza I, Sanchez LM, Allende MT, Vizoso F, Ruibal A, Lopez-Otin C (1993) Znalpha 2-glycoprotein levels in breast cancer cytosols and correlation with clinical, histological and biochemical parameters. Eur J Cancer 29A (9):1256-1260. [PubMed: 8343263]

[63] Huang Y, Li LZ, Zhang CZ, Yi C, Liu LL, Zhou X, Xie GB, Cai MY, Li Y, Yun JP (2012) Decreased expression of zinc-alpha2-glycoprotein in hepatocellular carcinoma associates with poor prognosis. J Transl Med 10 (1):106. [PubMed: 22625427]

[64] Xu H, Wei Y, Zhang Y, Xu Y, Li F, Liu J, Zhang W, Han X, Tan R, Shen P (2012) Oestrogen attenuates tumour progression in hepatocellular carcinoma. J Pathol 228 (2): 216-229. [PubMed: 22374713]

[65] Gold SM, Sasidhar MV, Morales LB, Du S, Sicotte NL, Tiwari-Woodruff SK, Voskuhl RR (2009) Estrogen treatment decreases matrix metalloproteinase (MMP)-9 in autoimmune demyelinating disease through estrogen receptor alpha (ERalpha). Lab Invest 89 (10):1076-1083. [PubMed: 19668239]

[66] Claassen H, Steffen R, Hassenpflug J, Varoga D, Wruck CJ, Brandenburg LO, Pufe T (2010) 17beta-estradiol reduces expression of MMP-1, -3, and -13 in human primary articular chondrocytes from female patients cultured in a three dimensional alginate system. Cell Tissue Res 342 (2):283-293. [PubMed: 20941509]

[67] Zhou H, Kimura K, Orita T, Nishida T, Sonoda KH (2011) Inhibition by female sex hormones of collagen degradation by corneal fibroblasts. Mol Vis 17:3415-3422. [PubMed: 22219637]

[68] Nelson AR, Fingleton B, Rothenberg ML, Matrisian LM (2000) Matrix metalloproteinases: biologic activity and clinical implications. J Clin Oncol 18 (5):1135-1149. [PubMed: 10694567]

[69] McCawley LJ, Matrisian LM (2001) Matrix metalloproteinases: they're not just for matrix anymore! Curr Opin Cell Biol 13 (5):534-540. [PubMed: 11544020]

[70] Demers M, Couillard J, Belanger S, St-Pierre Y (2005) New roles for matrix metalloproteinases in metastasis. Crit Rev Immunol 25 (6):493-523. [PubMed: 16390324]

[71] Brinckerhoff CE, Rutter JL, Benbow U (2000) Interstitial collagenases as markers of tumor progression. Clin Cancer Res 6 (12):4823-4830. [PubMed: 11156241]

[72] Sternlicht MD, Werb Z (2001) How matrix metalloproteinases regulate cell behavior. Annu Rev Cell Dev Biol 17:463-516. [PubMed: 11687497]

[73] Egeblad M, Werb Z (2002) New functions for the matrix metalloproteinases in cancer progression. Nat Rev Cancer 2 (3):161-174. [PubMed: 11990853]

[74] Turk V, Kos J, Turk B (2004) Cysteine cathepsins (proteases)--on the main stage of cancer? Cancer Cell 5 (5):409-410. [PubMed: 15144947] 
[75] Rifkin DB, Mazzieri R, Munger JS, Noguera I, Sung J (1999) Proteolytic control of growth factor availability. APMIS 107 (1):80-85. [PubMed: 10190283]

[76] Manes S, Llorente M, Lacalle RA, Gomez-Mouton C, Kremer L, Mira E, Martinez AC (1999) The matrix metalloproteinase-9 regulates the insulin-like growth factor-triggered autocrine response in DU-145 carcinoma cells. J Biol Chem 274 (11):6935-6945. [PubMed: 10066747]

[77] Noe V, Fingleton B, Jacobs K, Crawford HC, Vermeulen S, Steelant W, Bruyneel E, Matrisian LM, Mareel M (2001) Release of an invasion promoter E-cadherin fragment by matrilysin and stromelysin-1. J Cell Sci 114 (Pt 1):111-118. [PubMed: 11112695]

[78] Fingleton B, Vargo-Gogola T, Crawford HC, Matrisian LM (2001) Matrilysin [MMP-7] expression selects for cells with reduced sensitivity to apoptosis. Neoplasia 3 (6):459-468. [PubMed: 11774028]

[79] Yu Q, Stamenkovic I (2000) Cell surface-localized matrix metalloproteinase-9 proteolytically activates TGF-beta and promotes tumor invasion and angiogenesis. Genes Dev 14 (2):163-176. [PubMed: 10652271]

[80] Stetler-Stevenson WG (1999) Matrix metalloproteinases in angiogenesis: a moving target for therapeutic intervention. J Clin Invest 103 (9):1237-1241. [PubMed: 10225966]

[81] Dong Z, Kumar R, Yang X, Fidler IJ (1997) Macrophage-derived metalloelastase is responsible for the generation of angiostatin in Lewis lung carcinoma. Cell 88 (6): 801-810. [PubMed: 9118223]

[82] Cornelius LA, Nehring LC, Harding E, Bolanowski M, Welgus HG, Kobayashi DK, Pierce RA, Shapiro SD (1998) Matrix metalloproteinases generate angiostatin: effects on neovascularization. J Immunol 161 (12):6845-6852. [PubMed: 9862716]

[83] Ferreras M, Felbor U, Lenhard T, Olsen BR, Delaisse J (2000) Generation and degradation of human endostatin proteins by various proteinases. FEBS Lett 486 (3): 247-251. [PubMed: 11119712]

[84] Jiang Y, Goldberg ID, Shi YE (2002) Complex roles of tissue inhibitors of metalloproteinases in cancer. Oncogene 21 (14):2245-2252. [PubMed: 11948407]

[85] Baker AH, George SJ, Zaltsman AB, Murphy G, Newby AC (1999) Inhibition of invasion and induction of apoptotic cell death of cancer cell lines by overexpression of TIMP-3. Br J Cancer 79 (9-10):1347-1355. [PubMed: 10188875]

[86] Yamamoto H, Itoh F, Adachi Y, Sakamoto H, Adachi M, Hinoda Y, Imai K (1997) Relation of enhanced secretion of active matrix metalloproteinases with tumor spread in human hepatocellular carcinoma. Gastroenterology 112 (4):1290-1296. [PubMed: 9098015]

[87] Theret N, Musso O, Turlin B, Lotrian D, Bioulac-Sage P, Campion JP, Boudjema K, Clement B (2001) Increased extracellular matrix remodeling is associated with tumor 
progression in human hepatocellular carcinomas. Hepatology 34 (1):82-88. [PubMed: 11431737]

[88] Ishii Y, Nakasato Y, Kobayashi S, Yamazaki Y, Aoki T (2003) A study on angiogenesis-related matrix metalloproteinase networks in primary hepatocellular carcinoma. J Exp Clin Cancer Res 22 (3):461-470. [PubMed: 14582707]

[89] McKenna GJ, Chen Y, Smith RM, Meneghetti A, Ong C, McMaster R, Scudamore CH, Chung SW (2002) A role for matrix metalloproteinases and tumor host interaction in hepatocellular carcinomas. Am J Surg 183 (5):588-594. [PubMed: 12034400]

[90] Sawada S, Murakami K, Murata J, Tsukada K, Saiki I (2001) Accumulation of extracellular matrix in the liver induces high metastatic potential of hepatocellular carcinoma to the lung. Int J Oncol 19 (1):65-70. [PubMed: 11408924]

[91] Maatta M, Soini Y, Liakka A, Autio-Harmainen H (2000) Differential expression of matrix metalloproteinase (MMP)-2, MMP-9, and membrane type 1-MMP in hepatocellular and pancreatic adenocarcinoma: implications for tumor progression and clinical prognosis. Clin Cancer Res 6 (7):2726-2734. [PubMed: 10914717]

[92] Cui J, Dong BW, Liang P, Yu XL, Yu DJ (2004) Effect of c-myc, Ki-67, MMP-2 and VEGF expression on prognosis of hepatocellular carcinoma patients undergoing tumor resection. World J Gastroenterol 10 (10):1533-1536. [PubMed: 15133868]

[93] Zhang Q, Chen X, Zhou J, Zhang L, Zhao Q, Chen G, Xu J, Qian F, Chen Z (2006) CD147, MMP-2, MMP-9 and MVD-CD34 are significant predictors of recurrence after liver transplantation in hepatocellular carcinoma patients. Cancer Biol Ther 5 (7): 808-814. [PubMed: 16775432]

[94] Gao ZH, Tretiakova MS, Liu WH, Gong C, Farris PD, Hart J (2006) Association of Ecadherin, matrix metalloproteinases, and tissue inhibitors of metalloproteinases with the progression and metastasis of hepatocellular carcinoma. Mod Pathol 19 (4): 533-540. [PubMed: 16474379]

[95] Arii S, Mise M, Harada T, Furutani M, Ishigami S, Niwano M, Mizumoto M, Fukumoto M, Imamura M (1996) Overexpression of matrix metalloproteinase 9 gene in hepatocellular carcinoma with invasive potential. Hepatology 24 (2):316-322. [PubMed: 8690399]

[96] Hayasaka A, Suzuki N, Fujimoto N, Iwama S, Fukuyama E, Kanda Y, Saisho H (1996) Elevated plasma levels of matrix metalloproteinase-9 (92-kd type IV collagenase/gelatinase B) in hepatocellular carcinoma. Hepatology 24 (5):1058-1062. [PubMed: 8903375]

[97] Sakamoto Y, Mafune K, Mori M, Shiraishi T, Imamura H, Takayama T, Makuuchi M (2000) Overexpression of MMP-9 correlates with growth of small hepatocellular carcinoma. Int J Oncol 17 (2):237-243. [PubMed: 10891530]

[98] Harada T, Arii S, Mise M, Imamura T, Higashitsuji H, Furutani M, Niwano M, Ishigami S, Fukumoto M, Seiki M, Sato H, Imamura M (1998) Membrane-type matrix 
metalloproteinase-1(MT1-MTP) gene is overexpressed in highly invasive hepatocellular carcinomas. J Hepatol 28 (2):231-239. [PubMed: 9514536]

[99] Chen X, Cheung ST, So S, Fan ST, Barry C, Higgins J, Lai KM, Ji J, Dudoit S, Ng IO, Van De Rijn M, Botstein D, Brown PO (2002) Gene expression patterns in human liver cancers. Mol Biol Cell 13 (6):1929-1939. [PubMed: 12058060]

[100] Ip YC, Cheung ST, Leung KL, Fan ST (2005) Mechanism of metastasis by membrane type 1-matrix metalloproteinase in hepatocellular carcinoma. World J Gastroenterol 11 (40):6269-6276. [PubMed: 16419154]

[101] Bosch FX, Ribes J, Borras J (1999) Epidemiology of primary liver cancer. Semin Liver Dis 19 (3):271-285. [PubMed: 10518307]

[102] Poon RT, Fan ST, Lo CM, Liu CL, Ng IO, Wong J (2000) Long-term prognosis after resection of hepatocellular carcinoma associated with hepatitis B-related cirrhosis. J Clin Oncol 18 (5):1094-1101. [PubMed: 10694562]

[103] Giannelli G, Bergamini C, Fransvea E, Marinosci F, Quaranta V, Antonaci S (2001) Human hepatocellular carcinoma (HCC) cells require both alpha3beta1 integrin and matrix metalloproteinases activity for migration and invasion. Lab Invest 81 (4): 613-627. [PubMed: 11304581]

[104] Chen R, Cui J, Xu C, Xue T, Guo K, Gao D, Liu Y, Ye S, Ren Z (2012) The Significance of MMP-9 Over MMP-2 in HCC Invasiveness and Recurrence of Hepatocellular Carcinoma After Curative Resection. Ann Surg Oncol 19 Suppl 3:375-384. [PubMed: 21681378]

[105] Ng KT, Qi X, Kong KL, Cheung BY, Lo CM, Poon RT, Fan ST, Man K (2011) Overexpression of matrix metalloproteinase-12 (MMP-12) correlates with poor prognosis of hepatocellular carcinoma. Eur J Cancer 47 (15):2299-2305. [PubMed: 21683576]

[106] Stamenkovic I (2000) Matrix metalloproteinases in tumor invasion and metastasis. Semin Cancer Biol 10 (6):415-433. [PubMed: 11170864]

[107] Akriviadis EA, Llovet JM, Efremidis SC, Shouval D, Canelo R, Ringe B, Meyers WC (1998) Hepatocellular carcinoma. Br J Surg 85 (10):1319-1331. [PubMed: 9782009]

[108] Ozaki T, Mochizuki H, Ichikawa Y, Fukuzawa Y, Yoshida S, Morimoto M (2000) Persistence of hepatitis B surface antibody levels after vaccination with a recombinant hepatitis B vaccine: a 3-year follow-up study. J Oral Sci 42 (3):147-150. [PubMed: 11111325]

[109] Milani S, Herbst H, Schuppan D, Grappone C, Pellegrini G, Pinzani M, Casini A, Calabro A, Ciancio G, Stefanini F, et al. (1994) Differential expression of matrix-metalloproteinase-1 and -2 genes in normal and fibrotic human liver. Am J Pathol 144 (3): 528-537. [PubMed: 8129038] 
[110] Benyon RC, Iredale JP, Goddard S, Winwood PJ, Arthur MJ (1996) Expression of tissue inhibitor of metalloproteinases 1 and 2 is increased in fibrotic human liver. Gastroenterology 110 (3):821-831. [PubMed: 8608892]

[111] Kapranos N, Karaiossifidi H, Kouri E, Vasilaros S (1996) Nm23 expression in breast ductal carcinomas: a ten year follow-up study in a uniform group of node-negative breast cancer patients. Anticancer Res 16 (6C):3987-3990. [PubMed: 9042324]

[112] Takahara T, Furui K, Yata Y, Jin B, Zhang LP, Nambu S, Sato H, Seiki M, Watanabe A (1997) Dual expression of matrix metalloproteinase-2 and membrane-type 1-matrix metalloproteinase in fibrotic human livers. Hepatology 26 (6):1521-1529. [PubMed: 9397993]

[113] Altadill A, Rodriguez M, Gonzalez LO, Junquera S, Corte MD, Gonzalez-Dieguez ML, Linares A, Barbon E, Fresno-Forcelledo M, Rodrigo L, Vizoso FJ (2009) Liver expression of matrix metalloproteases and their inhibitors in hepatocellular carcinoma. Dig Liver Dis 41 (10):740-748. [PubMed: 19372066]

[114] Preaux AM, Mallat A, Nhieu JT, D'Ortho MP, Hembry RM, Mavier P (1999) Matrix metalloproteinase-2 activation in human hepatic fibrosis regulation by cell-matrix interactions. Hepatology 30 (4):944-950. [PubMed: 10498646]

[115] Nakatsukasa H, Ashida K, Higashi T, Ohguchi S, Tsuboi S, Hino N, Nouso K, Urabe Y, Kinugasa N, Yoshida K, Uematsu S, Ishizaki M, Kobayashi Y, Tsuji T (1996) Cellular distribution of transcripts for tissue inhibitor of metalloproteinases 1 and 2 in human hepatocellular carcinomas. Hepatology 24 (1):82-88. [PubMed: 8707287]

[116] Zhang H, Wang YS, Han G, Shi Y (2007) TIMP-3 gene transfection suppresses invasive and metastatic capacity of human hepatocarcinoma cell line HCC-7721. Hepatobiliary Pancreat Dis Int 6 (5):487-491. [PubMed: 17897911]

[117] Roeb E, Bosserhoff AK, Hamacher S, Jansen B, Dahmen J, Wagner S, Matern S (2005) Enhanced migration of tissue inhibitor of metalloproteinase overexpressing hepatoma cells is attributed to gelatinases: relevance to intracellular signaling pathways. World J Gastroenterol 11 (8):1096-1104. [PubMed: 15754388]

[118] Taras D, Blanc JF, Rullier A, Dugot-Senant N, Laurendeau I, Vidaud M, Rosenbaum J (2007) Pravastatin reduces lung metastasis of rat hepatocellular carcinoma via a coordinated decrease of MMP expression and activity. J Hepatol 46 (1):69-76. [PubMed: 16935385]

[119] Xu J, Xu HY, Zhang Q, Song F, Jiang JL, Yang XM, Mi L, Wen N, Tian R, Wang L, Yao H, Feng Q, Zhang Y, Xing JL, Zhu P, Chen ZN (2007) HAb18G/CD147 functions in invasion and metastasis of hepatocellular carcinoma. Mol Cancer Res 5 (6):605-614. [PubMed: 17579119]

[120] Yeh CB, Hsieh MJ, Hsieh YH, Chien MH, Chiou HL, Yang SF (2012) Antimetastatic effects of norcantharidin on hepatocellular carcinoma by transcriptional inhibition of 
MMP-9 through modulation of NF-kB activity. PLoS One 7 (2):e31055. [PubMed: 22363545]

[121] Chen RX, Xia YH, Xue TC, Zhang H, Ye SL (2011) Down-regulation of osteopontin inhibits metastasis of hepatocellular carcinoma cells via a mechanism involving MMP-2 and uPA. Oncol Rep 25 (3):803-808. [PubMed: 21174062]

[122] Duffy MJ, Duffy GJ (1978) Estradiol receptors in human liver. J Steroid Biochem 9 (3): 233-235. [PubMed: 651349]

[123] Macdonald JS, Lippman ME, Woolley PV, Petrucci PP, Schein PS (1978) Hepatic estrogen and progesterone receptors in an estrogen-associated hepatic neoplasm. Cancer Chemother Pharmacol 1 (3):135-138. [PubMed: 373914]

[124] Friedman MA, Demanes DJ, Hoffman PG, Jr. (1982) Hepatomas: hormone receptors and therapy. Am J Med 73 (3):362-366. [PubMed: 6289660]

[125] Bojar H, Schutte J, Staib W, Broelsch C (1982) Does human liver contain estrogen receptors? A comparative study of estrogen binding in human and rodent liver. Klin Wochenschr 60 (8):417-425. [PubMed: 7098385]

[126] Porter LE, Elm MS, Van Thiel DH, Dugas MC, Eagon PK (1983) Characterization and quantitation of human hepatic estrogen receptor. Gastroenterology 84 (4):704-712. [PubMed: 6825981]

[127] Iqbal MJ, Wilkinson ML, Johnson PJ, Williams R (1983) Sex steroid receptor proteins in foetal, adult and malignant human liver tissue. Br J Cancer 48 (6):791-796. [PubMed: 6317004]

[128] Nagasue N, Ito A, Yukaya H, Ogawa Y (1986) Estrogen receptors in hepatocellular carcinoma. Cancer 57 (1):87-91. [PubMed: 3000573]

[129] Negro F, Papotti M, Pacchioni D, Galimi F, Bonino F, Bussolati G (1994) Detection of human androgen receptor mRNA in hepatocellular carcinoma by in situ hybridisation. Liver 14 (4):213-219. [PubMed: 7968281]

[130] Kohigashi K, Fukuda Y, Imura H (1987) Estrogen receptors in hepatocellular carcinoma: is endocrine therapy for hepatocellular carcinoma likely to be effective? Gastroenterol Jpn 22 (3):322-330. [PubMed: 3040510]

[131] Ohnami S, Nakata H, Nagafuchi Y, Zeze F, Eto S (1988) [Estrogen receptors in human gastric, hepatocellular, and gallbladder carcinomas and normal liver tissues]. Gan To Kagaku Ryoho 15 (10):2923-2928. [PubMed: 2845868]

[132] Nagasue N, Kohno H, Chang YC, Hayashi T, Utsumi Y, Nakamura T, Yukaya H (1989) Androgen and estrogen receptors in hepatocellular carcinoma and the surrounding liver in women. Cancer 63 (1):112-116. [PubMed: 2535950] 
[133] Hamazaki K, Miura H, Sakai H, Sato S, Yunoki M, Miichi N, Noda T, Mori M, Orita $\mathrm{K}$ (1989) [Estrogen and androgen receptors in hepatocellular carcinoma and in noncancerous liver tissue]. Gan No Rinsho 35 (10):1109-1113. [PubMed: 2550681]

[134] Nagasue N, Kohno H, Chang Y, Hayashi T, Nakamura T (1990) Specificity of androgen receptors of hepatocellular carcinoma and liver in humans. Hepatogastroenterology 37 (5):474-479. [PubMed: 2174826]

[135] Eagon PK, Francavilla A, DiLeo A, Elm MS, Gennari L, Mazzaferro V, Colella G, Van Thiel DH, Strazl TE (1991) Quantitation of estrogen and androgen receptors in hepatocellular carcinoma and adjacent normal human liver. Dig Dis Sci 36 (9):1303-1308. [PubMed: 1654243]

[136] Pacchioni D, Papotti M, Andorno E, Bonino F, Mondardini A, Oliveri F, Brunetto M, Bussolati G, Negro F (1993) Expression of estrogen receptor mRNA in tumorous and non-tumorous liver tissue as detected by in situ hybridization. J Surg Oncol Suppl 3:14-17. [PubMed: 8389161]

[137] Wang AG, Lee KY, Kim SY, Choi JY, Lee KH, Kim WH, Wang HJ, Kim JM, Park MG, Yeom YI, Kim NS, Yu DY, Lee DS (2006) The expression of estrogen receptors in hepatocellular carcinoma in Korean patients. Yonsei Med J 47 (6):811-816. [PubMed: 17191310]

[138] Wong LY, Chan SH, Oon CJ, Rauff A (1984) Immunocytochemical localization of testosterone in human hepatocellular carcinoma. Histochem J 16 (6):687-692. [PubMed: 6330003]

[139] Ohnishi S, Murakami T, Moriyama T, Mitamura K, Imawari M (1986) Androgen and estrogen receptors in hepatocellular carcinoma and in the surrounding noncancerous liver tissue. Hepatology 6 (3):440-443. [PubMed: 3011631]

[140] Nagasue N, Kohno H, Yamanoi A, Kimoto T, Chang YC, Nakamura T (1991) Progesterone receptor in hepatocellular carcinoma. Correlation with androgen and estrogen receptors. Cancer 67 (10):2501-2505. [PubMed: 1849788]

[141] Francavilla A, Panella C, Amoruso A, Giangaspero A, Gennari L, Mazzaferro V, Colella G, Van Thiel DH, Starzl TE (1991) Role of estrogens and epidermal growth factor in hepatocellular carcinoma (HCC). Dig Dis Sci 36 (9):1299-1302. [PubMed: 1654242]

[142] Villa E, Camellini L, Dugani A, Zucchi F, Grottola A, Merighi A, Buttafoco P, Losi L, Manenti F (1995) Variant estrogen receptor messenger RNA species detected in human primary hepatocellular carcinoma. Cancer Res 55 (3):498-500. [PubMed: 7834616]

[143] Ng IO, Ng M, Fan ST (1997) Better survival in women with resected hepatocellular carcinoma is not related to tumor proliferation or expression of hormone receptors. Am J Gastroenterol 92 (8):1355-1358. [PubMed: 9260806] 
[144] Villa E, Dugani A, Moles A, Camellini L, Grottola A, Buttafoco P, Merighi A, Ferretti I, Esposito P, Miglioli L, Bagni A, Troisi R, De Hemptinne B, Praet M, Callea F, Manenti F (1998) Variant liver estrogen receptor transcripts already occur at an early stage of chronic liver disease. Hepatology 27 (4):983-988. [PubMed: 9537437]

[145] Iavarone M, Lampertico P, Seletti C, Francesca Donato M, Ronchi G, del Ninno E, Colombo M (2003) The clinical and pathogenetic significance of estrogen receptor-beta expression in chronic liver diseases and liver carcinoma. Cancer 98 (3):529-534. [PubMed: 12879470]

[146] Moon WS, Chang K, Tarnawski AS (2004) Overexpression of metastatic tumor antigen 1 in hepatocellular carcinoma: Relationship to vascular invasion and estrogen receptor-alpha. Hum Pathol 35 (4):424-429. [PubMed: 15116322]

[147] Xing BC, Wang JH, Wang Y, Hao CY, Huang XF (2004) [Expression of wild type and variant estrogen receptors in human hepatocellular carcinoma]. Beijing Da Xue Xue Bao 36 (6):620-622. [PubMed: 15605095]

[148] Meza-Junco J, Montano-Loza AJ, Gamboa-Dominguez A, Green-Renner D (2007) Expression of oestrogen and growth factor receptors in hepatocellular carcinoma. Clin Oncol (R Coll Radiol) 19 (10):801-802. [PubMed: 17822888]

[149] Nagasue N, Ito A, Yukaya H, Ogawa Y (1985) Androgen receptors in hepatocellular carcinoma and surrounding parenchyma. Gastroenterology 89 (3):643-647. [PubMed: 2991072]

[150] Wilkinson ML, Iqbal MJ, Williams R (1985) Characterisation of high affinity binding sites of androgens in primary hepatocellular carcinoma. Clin Chim Acta 152 (1-2): 105-113. [PubMed: 2414040]

[151] Bannister P, Meystre CM, Losowsky MS (1988) Androgen receptor concentrations in needle biopsy specimens of human liver. Liver 8 (1):28-31. [PubMed: 3367706]

[152] Nagasue N, Yamanoi A, Kohno H, Kimoto T, Chang Y, Taniura H, Uchida M, Nakamura T (1992) Androgen receptor in cirrhotic liver, adenomatous hyperplastic nodule and hepatocellular carcinoma in the human. Hepatogastroenterology 39 (5): 455-460. [PubMed: 1334038]

[153] Tavian D, De Petro G, Pitozzi A, Portolani N, Giulini SM, Barlati S (2002) Androgen receptor mRNA under-expression in poorly differentiated human hepatocellular carcinoma. Histol Histopathol 17 (4):1113-1119. [PubMed: 12371139]

[154] Engstrom PF, Levin B, Moertel CG, Schutt A (1990) A phase II trial of tamoxifen in hepatocellular carcinoma. Cancer 65 (12):2641-2643. [PubMed: 2160313]

[155] Castells A, Bruix J, Bru C, Ayuso C, Roca M, Boix L, Vilana R, Rodes J (1995) Treatment of hepatocellular carcinoma with tamoxifen: a double-blind placebo-controlled trial in 120 patients. Gastroenterology 109 (3):917-922. [PubMed: 7657122] 
[156] Liu CL, Fan ST, Ng IO, Lo CM, Poon RT, Wong J (2000) Treatment of advanced hepatocellular carcinoma with tamoxifen and the correlation with expression of hormone receptors: a prospective randomized study. Am J Gastroenterol 95 (1):218-222. [PubMed: 10638587]

[157] Villa E, Ferretti I, Grottola A, Buttafoco P, Buono MG, Giannini F, Manno M, Bertani H, Dugani A, Manenti F (2001) Hormonal therapy with megestrol in inoperable hepatocellular carcinoma characterized by variant oestrogen receptors. Br J Cancer 84 (7):881-885. [PubMed: 11286465]

[158] Chow PK, Tai BC, Tan CK, Machin D, Win KM, Johnson PJ, Soo KC (2002) High-dose tamoxifen in the treatment of inoperable hepatocellular carcinoma: A multicenter randomized controlled trial. Hepatology 36 (5):1221-1226. [PubMed: 12395333] 